\title{
Hypoplastic left heart syndrome and 45X karyotype
}

\author{
H VAN EGMOND, * E ORYE, * M PRAET, $\dagger$ M COPPENS,$\dagger$ \\ A DEVLOO-BLANCQUAERT * \\ From the ${ }^{\star}$ Paediatric Cardiology and Genetic Department, and $\dagger$ Department of Pathology, University \\ Hospital, State University of Ghent, Belgium
}

SUMMARY A review of 63 patients with 45X karyotype (Turner's syndrome) admitted to a hospital from 1972 to 1985 showed that $20(32 \%)$ had one or more major cardiac malformations (mostly coarctation and aortic stenosis). Four $(20 \%)$ died in the neonatal period. One infant had mitral stenosis and severe aortic stenosis and died at the age of 35 days. The three $(15 \%)$ other patients who died had a typical hypoplastic left heart syndrome, with an atretic aortic valve in two and pinpoint aortic valve in one. Turner's syndrome was clinically suspected in three of the cases. One of these had mosaicism $(46 X X, 45 X)$ the others had a $45 X$ pattern. During the same period (1972$85) 39$ patients (14 girls and 25 boys) were admitted with diagnosis of hypoplastic left heart syndrome. Three (21.4\%) girls had a $45 \mathrm{X}$ karyotype. The high incidence of hypoplastic left heart syndrome in Turner's syndrome and of Turner's syndrome in girls with hypoplastic left heart syndrome suggests that hypoplastic left heart syndrome can be another expression of the $45 \mathrm{X}$ karyotype.

In 1938 Turner described a syndrome of infantilism, congenital webbed neck, and cubitus valgus. ${ }^{1}$ It has been shown that gonadal dysgenesis is an almost invariable feature of this syndrome. Other frequent anomalies associated with this syndrome are small stature and lymphoedema of the extremities during the first year of life. In 1959 the first chromosome study showed that one $\mathrm{X}$ chromosome was absent in female patients with Turner's syndrome. ${ }^{2}$ This discovery confirmed the earlier findings that many of these patients did not have sex chromatin in a smear of buccal cells. In addition to the absence of one $\mathrm{X}$ chromosome, which is the usual finding, various structural anomalies of the second $\mathrm{X}$ chromosome have been described. ${ }^{3}$ Many other congenital malformations have been reported in this condition. ${ }^{4}$ There are left sided congenital cardiac anomalies in $20 \%$ $40 \%$ of patients with Turner's syndrome. ${ }^{5-7}$ The most common is coarctation of the aorta. Less commonly reported are cases of isolated aortic stenosis, ventricular septal defect, atrial septal defect, subaortic stenosis, and idiopathic systemic hyperten-

Requests for reprints to Dr $\mathrm{H}$ van Egmond, University Hospital, Kliniek voor Kinderziekten "C Hooft", Department of Paediatric Cardiology, De Pintelaan 185, B-9000 Ghent, Belgium.

Accepted for publication 2 February 1988 sion. Isolated non-stenotic bicuspid aortic valve was found on echocardiography in $34^{\circ}{ }_{0}$, of the cases. ${ }^{8}$ Hypoplastic left heart syndrome had occasionally been reported with Turner's syndrome. ${ }^{910}$

We reviewed a series of 63 patients with Turner's syndrome admitted to our hospital from 1972 to 1985. Twenty patients had one or more cardiac malformations (mostly coarctation and aortic stenosis), an incidence series in keeping with reported findings. Four $\left(20^{\circ}{ }_{0}\right)$ of these patients died in the neonatal period. One patient showed moderate mitral stenosis and severe aortic stenosis; the other three had typical hypoplastic left heart syndrome.

\section{Patients and methods}

Between 1972 and 1985 four patients with Turner's syndrome died in the neonatal period of congenital heart disease. The table summarises data on their chromosomes and phenotypes. Typically, hypoplastic left heart syndrome caused cyanosis, tachycardia, tachypnoea, and heart failure. In two cases a heart murmur was noted and peripheral pulses were palpable in two cases. All cases had considerable oedema of the hands and feet. The diagnosis of hypoplastic left heart syndrome was confirmed by cardiac catheterisation in two cases; in the third case diagnosis was made by echocardiography only. 
Table Data on phenotype and chromosomes in four neonates with Turner's syndrome and hypoplastic left heart syndrome

\begin{tabular}{|c|c|c|c|c|c|}
\hline Patient & $\begin{array}{l}\text { Birthweight } \\
\text { (g) }\end{array}$ & $\begin{array}{l}\text { Ages at } \\
\text { admission and } \\
\text { death (days) }\end{array}$ & Phenotype & Necropsy data & $\begin{array}{l}\text { Chromosoma } \\
\text { analysis }\end{array}$ \\
\hline 1 & 3250 & 14,41 & Normal & $\begin{array}{l}\text { Mitral stenosis, aortic stenosis, ductus } \\
\text { arteriosus }\end{array}$ & $45 X$ \\
\hline 2 & 2700 & 15,17 & $\begin{array}{l}\text { Pterygium colli, flat thorax, widely } \\
\text { spaced nipples, oedema of hands } \\
\text { and feet }\end{array}$ & $\begin{array}{l}\text { Pinpoint aortic stenosis, hypoplastic } \\
\text { left ventricle, rudimentary mitral } \\
\text { valve, ductus arteriosus }\end{array}$ & $45 X$ \\
\hline 3 & 3100 & 1,2 & $\begin{array}{l}\text { Typical facies, flat thorax, webbed } \\
\text { neck, oedema of hands and feet }\end{array}$ & $\begin{array}{l}\text { Aortic atresia, rudimentary mitral } \\
\text { valve, ductus arteriosus }\end{array}$ & $\begin{array}{l}45 \% 45 X \\
55 \% 46 X X\end{array}$ \\
\hline 4 & 2930 & 2,3 & $\begin{array}{l}\text { Typical facies, webbed neck, flat } \\
\text { thorax, widely spaced nipples, } \\
\text { cubitus valgus, oedema of hands } \\
\text { and feet }\end{array}$ & $\begin{array}{l}\text { Aortic atresia, hypoplastic mitral } \\
\text { valve, ductus arteriosus }\end{array}$ & $45 X$ \\
\hline
\end{tabular}

\section{Results}

\section{FINDINGS AT NECROPSY}

Case 1

This heart showed cardiomegaly caused by left ventricular enlargement, the cardiac apex being entirely made up of the tissue of the left chamber. When the heart was opened severe fibroelastosis of the endocardium was found to be especially widespread in the left ventricle. The oval foramen was small, functionally closed but probe patent. Examination of the right heart showed a normal atrium, ventricle, tricuspid valve, and pulmonary valve. The left atrium and auricle were dilated. There were multiple cysts of Lushka on the anterior cusp of the mitral valve. The papillary muscles were fibrotic and the chordae tendineae were shortened. The left ventricle was hypertrophic, with a bicuspid and stenotic aortic valve (diameter $3.2 \mathrm{~mm}$ compared with $10.5 \mathrm{~mm}$ for the pulmonary valve). The ascending aorta and the pulmonary trunk were dilated. The ductus arteriosus was probe patent and fibrotic.

The diagnosis was bicuspid and stenotic aortic valve with hypertrophy and enlarged (fibroelastosis) left heart with a relatively small but probe-patent oval foramen.

\section{Case 2}

The right atrial appendage was enlarged. The diameter of the oval foramen was small but it admitted a probe. The tricuspid valve, right ventricle, and pulmonary valve were normal. There was a non-obstructive rim between the pulmonary veins and the bottom of the left atrium. The mitral valve was very small (diameter $1.3 \mathrm{~mm}$ ). The wall of the left ventricle was made up of hyperplastic muscular tissue. The aortic valve (diameter $1.0 \mathrm{~mm}$ ) and the ascending aorta were hypoplastic. The aortic arch was interrupted between the left carotid artery and the left subclavian artery. The right and the left subclavian arteries originated from the descending aorta. The large diameter ductus was functionally and anatomically patent. Unusually there was amedian artery between the two carotid arteries. It bifurcated after $5 \mathrm{~mm}$. This was taken to be remnantso of the anterior aorta and both first aortic arches, which normally regress.

The diagnosis was left heart hypoplasia, rudimen $\stackrel{\stackrel{c}{<}}{<}$ tary mitral valve, extremely hypoplastic left ventricle $\vec{\bullet}$ and ascending aorta, pinpoint aortic valve, interrup- $-\infty$ tion of the aortic arch, aberrant right subclavian. artery, and a small probe-patent oval foramen.

Case 3

The right atrium and auricle were dilated and enlarged. The tricuspid valve, the right ventricle, $\mathbb{\triangle}$ and the pulmonary valve were normal. The left $\vec{F}$ atrium and left auricle were small and there was a $\frac{3}{3}$ type II atrial septal defect. The mitral valve and the left ventricle were rudimentary and the aortic valve was atretic. A large open ductus arteriosus connected a narrow ascending aorta with the pulmonary trunk. $\overparen{D}$ The diagnosis was left heart hypoplasia, rudimentary? mitral valve and left ventricle, and atresia of the aortic valve.

Case 4

Both atria and a small left ventricle were located 0 behind an anterior right ventricle. The right atrium and auricle were enlarged. Both the tricuspid valve and the right ventricle were normal. The oval foramen was covered by a membrane with two small o openings. The left atrium and auricle were normal. $N$ The mitral valve $(4 \mathrm{~mm})$, the left ventricle $(6 \mathrm{~mm})$, ㅆ and the ascending aorta were hypoplastic and the 0 aortic valve was atretic. Inspection of the vascular tree showed a dilated pulmonary trunk, a widely patent ductus arteriosus, and an aberrant right $\stackrel{\oplus}{?}$ subclavian artery. The diagnosis was left heart hypo- 7 plasia, aortic atresia, and considerable hypoplasia of the left ventricle, ascending aorta, and mitral valve, $\stackrel{\mathbb{D}}{\Omega}$ with an aberrant right subclavian artery and a type II $\mathbb{\otimes}$ atrial septal defect. 


\section{Discussion}

In three of these four cases of Turner's syndrome a 45X karyotype was suspected on clinical grounds. All three had hypoplastic left heart syndrome. In the fourth case clinical examination was normal and moderate mitral stenosis and severe aortic stenosis were found at necropsy. One patient had mosaicism (45X, 46XX karyotype) and the other three had a 45X karyotype.

In the same period (1972-85) we examined 39 (14 girls and 25 boys) patients with hypoplastic left heart syndrome. Thirteen of the girls had chromosomal analysis: three $(21 \%)$ had a $45 \mathrm{X}$ karyotype (one mosaicism $45 \mathrm{X}, 46 \mathrm{X}$ ) and in the others the chromosomal pattern was normal.

In a series of 1498 aborted fetuses with hypoplastic left heart syndrome chromosomal analysis showed the $45 \mathrm{X}$ karyotype in $18.7 \%{ }^{11} \mathrm{~A}$ high lethality is unusual in $\mathrm{X}$ linked anomalies, where the clinical expression of the anomaly is high, and the lethal effect is much less than in autosomal aneuploidy. ${ }^{12}$ The flow theory postulates that coarctation is the result of left ventricular obstructive disease in the fetus that reduces the flow through the ascending aorta and the aortic arch and increases the flow through the pulmonary artery truncus. ${ }^{13}$ Because many patients with Turner's syndrome and cardiac disease have coarctation and aortic stenosis a form of left obstructive disease would be expected in utero. Hypoplastic left heart syndrome is a severe left sided obstructive disease and it could be one of the causes of the high incidence of intrauterine death in patients with Turner's syndrome-only one out of $30045 \mathrm{X}$ conceptuses survived to birth. ${ }^{14}$ A study of the cardiovascular system and chromosomal typing in aborted fetuses is needed to investigate this suggestion.

\section{References}

1 Turner HH. A syndrome of infantilism, congenital webbed neck and cubitus valgus. Endocrinology 1938;23:566-74.

2 Ford CE, Jones KW, Polani PE, de Almeida JC, Briggs $\mathrm{JH}$. A sex chromosome anomaly in a case of gonadal dysgenesis (Turner's syndrome). Lancet 1959;i:7113.

3 Palmer CG, Reichmann A. Chromosomal and clinical findings in 110 females with Turner's syndrome. Hum Genet 1976;35:35-49.

4 Haddad HM, Wilkins L. Congenital anomalies associated with gonadal aplasia: review of 55 cases. Pediatrics 1959;23:885-902.

5 Nora JJ, Torres FG, Sinha AK, McNamara DG. Characteristic cardiovascular anomalies of XO Turner's syndrome, $\mathrm{XX}$ and $\mathrm{XY}$ fenotype and $\mathrm{XO} / \mathrm{XX}$ Turner mosaicism. Am J Cardiol 1970;25:639-41.

6 Rainier-Pope CR, Cunningham RD, Nadas AS, Crigler JF. Cardiovascular malformations in Turner's syndrome. Pediatrics 1964;33:919-24.

7 Van der Hauwaert LG, Fryns JP, Dumoulin M, Logghe N. Cardiovascular malformations in Turner's and Noonan's syndrome. Br Heart $J$ 1978;40:500-9.

8 Miller MJ, Gaffner ME, Lippe BM, et al. Echocardiography reveals a high incidence of bicuspid aortic valve in Turner's syndrome. $J$ Pediatr 1983;102:4750.

9 Conem PE, Glass IG. 45/XO Turner's syndrome in the newborn: report of two cases. J Clin Endocrinol Metab 1963;23:1-10.

10 Lopez P. Hypoplastic left heart syndrome in a patient with 45X/46XX/47XXX mosaicism. Am J Med Genet 1978;2:341-3.

11 Boué J, Boué $\mathrm{A}$, Lasar $\mathrm{Ph}$. Retrospective and prospective epidemiological study of 1500 karyotypical spontaneous human abortions. Teratology 1975;12:11-26.

12 Epstein CJ. The lethality of monosomy X. In: The consequences of chromosome imbalance. Cambridge: Cambridge University Press, 1986:338-9.

13 Shinebourne EA, Elseed AM. Relation between fetal flow patterns, coarctation of the aorta, and pulmonary blood flow. Br Heart $J$ 1974;36:492-8.

14 Kayii T, Ferrier A, Niikawa N. Anatomic and chromosomal anomalies in 639 spontaneous abortions. Hum Genet 1980;55:87-98. 